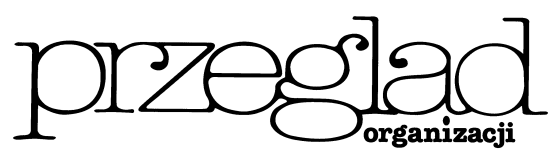

\title{
Kierunki przemian
}

we współczesnych korporacjach transnarodowych z sektora zaawansowanych technologii

https://doi.org/10.33141/po.2005.12.04

Michat Marte

\section{Wstęp}

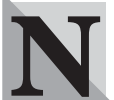

a przestrzeni ostatniego półwiecza korporacje transnarodowe zmieniały sposoby działania na rynku międzynarodowym. Wiązało się to $\mathrm{z}$ postępującym procesem globalizacji oraz rozwojem technologii informatycznych i komunikacyjnych. Zmniejszanie barier ograniczajacych swobodną wymianę gospodarczą, a przez to coraz łatwiejszy dostęp do krajowych rynków zbytu, sprawiało, że firmy lokalne stopniowo traciły swoją uprzywilejowaną pozycję na rodzimych rynkach względem firm zagranicznych. Strategie międzynarodowej ekspansji KTN (korporacji transnarodowych) ewoluowały w kierunku coraz bardziej efektywnego wykorzystywania globalnej skali działalności tych firm, poprzez jednoczesne pogłębianie integracji wewnętrznej organizacji i zwiększanie globalnej synchronizacji działań. Jest to zjawisko istotne dla polskich przedsiębiorstw, gdyż wiąże się z przenoszeniem części działań rozwojowych oraz usług opartych na najnowszych technologiach komunikacyjnych do krajów trzecich, w tym także do Polski ${ }^{1}$.

\section{Ogólne zmiany sposobów działania}

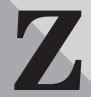

miany w działalności ponadgranicznej KTN uzależnione były od przemian, które stopniowo dokonywały się w sposobach działania tych organizacji.

W okresie międzywojennym i tuż po II wojnie światowej duże firmy wykazywały tendencję do eksploatowania potencjału gospodarczego zagranicznych rynków poprzez komercjalizowanie tam produktów i usług, do stworzenia których potrzebne były unikalne kompetencje wypracowane na macierzystym ryn$\mathrm{ku}^{2}$. W praktyce oznaczało to najczęściej skupianie się na działalności eksportowej oraz zakładanie na poszczególnych rynkach narodowych filii zagranicznych, które umożliwiały pokonywanie przeszkód związanych $\mathrm{z}$ barierami handlowymi, różnorodnymi standardami technologicznymi oraz dystrybucyjnymi ${ }^{3}$. W latach 60 . ub. wieku, a więc w okresie, kiedy bariery handlowe zaczęły być stopniowo likwidowane, KTN bardziej intensywnie rozbudowywały swoją międzynarodową infrastrukturę gospodarczą - zarówno sprzedażową, jak i wytwórczą ${ }^{4}$. Kolejny etap przemian rozpoczął się pod koniec lat 70. Wtedy to KTN zaczęły w coraz większym stopniu polegać na rozbudowanej już wcześniej międzynarodowej sieci swoich zagranicznych filii w celu wykorzystywania ich potencjału w różnorodnych
Przegląd Organizacji, Nr 12 (791), 2005, ss. 16-18 www.przegladorganizacji.pl Towarzystwo Naukowe Organizacji i Kierownictwa (TNOiK) obszarach biznesowych. Dzięki zwiększonej współpracy w ramach całej organizacji, KTN zaczęły wykorzystywać komplementarność wynikająca z akumulacji istniejących kompetencji, dywersyfikacji działań rozwojowych oraz umiędzynarodowienia technologii dostępnej korporacji ${ }^{5)}$.

Do końca lat 90. sposoby działania KTN zmieniły się więc z koncentrowania się na transferze technologii za granicę (przede wszystkim w postaci gotowych produktów - z centrali do zagranicznych filii) na organizowanie oraz zarządzanie tworzeniem innowacji i wiedzy, przy wykorzystaniu całej struktury swojej organizacji ${ }^{6)}$. Przez cały ten czas działalność KTN nastawiona była jednak na wykonywanie większości działań w ramach własnej organizacji oraz na maksymalne wykorzystywanie zasobów i umiejętności własnej organizacji, czyli internalizację.

\section{„Rozczłonkowywanie" łańcucha tworzenia wartości otwiera KTN na zewnątrz}

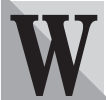

latach 90. ub. wieku zauważyć można początek kolejnej fali zmian w sposobach działalności KTN. Pogłębiający się proces globalizacji, presja na zwiększanie konkurencyjności, coraz doskonalsze technologie obliczeniowe oraz komunikacyjne sprawiły, że struktura KTN ulegać zaczęła kolejnym zmianom. Następowało widoczne „rozczłonkowywanie” ich łańcucha tworzenia wartości. KTN coraz częściej odchodziły od internalizacji działań i „otwierały” się na współpracę z zewnętrznymi firmami i instytucjami, aby wykorzystać ich specjalizację poprzez outsourcing. Zjawisko to dotyczyło w szczególności sektora zaawansowanych technologii (dokładniej w tzw. sektorach high-tech) i związane było ze zmianami źródeł tworzących wartość dodaną, czyli przede wszystkim ze zwrostem „zawartości” wiedzy w oferowanych produktach i usługach oraz zintensyfikowaniem działań innowacyjnych mniejszych firm. Postęp technologiczny doprowadził bowiem do sytuacji, w której nierozłączne do tej pory elementy łańcucha tworzenia wartości, a więc produkt i informacje, stały się ze sobą w mniejszym stopniu powiązane. Możliwe stało się więc „rozczłonkowanie”, czyli podzielenie łańcucha tworzenia wartości na odrębne poziomy $^{7)}$. Pierwszy z nich to poziom materialny, na który składają się kluczowe procesy produkcyjne oraz infrastruktura produkcyjna. Drugi, to poziom transakcyjny. Dotyczy on przetwarzania informacji związanych z obsługą klientów i dostawców. Poziom wiedzy 
natomiast związany jest z zarządzaniem wiedzą i działaniami innowacyjnymi.

W przypadku KTN z technologicznie zaawansowanych sektorów (np. IBM i Dell z sektora komputerowego), łańcuch tworzenia wartości stawał się coraz bardziej rozczłonkowany, a jednocześnie rozproszony globalnie. Prace badawczo-rozwojowe korporacji musiały więć nabrać charakteru dużo bardziej umiędzynarodowionego, a istotną rolę zaczęła odgrywać umiejętność wyszukiwania ze źródeł zewnętrznych potrzebnej wiedzy i innowacji. Coraz częściej okazywało się bowiem, że potrzebna wiedza i innowacje nie znajdują się w posiadaniu organizacji. Naturalną konsekwencją tego faktu było nawiązywanie współpracy międzyfirmowej poprzez tworzenie sieci partnerskich, wspólnych przedsięwzięć i umów partnerskich $\mathrm{z}$ wieloma zewnętrznymi firmami. Wszystkie te czynniki sprawiły, że pod koniec XX wieku pionowo zintegrowany łańcuch tworzenia wartości IBM bardzo szybko zaczął ustępować miejsca łańcuchom rozczłonkowanym, poziomo zintegrowanym i umiędzynarodowionym. W sektorze pojawiło się wiele nowych, wyspecjalizowanych firm. Rysunek 1 obrazuje zmianę w podejściu do produkcji komputerów na przestrzeni ostatnich 50 lat.

Korporacje z technologicznie zaawansowanych sektorów coraz częściej odchodzą lub sa zmuszane do odejścia od pełnej internalizacji działań wytwórczych, która stanowi podstawę opisanego przez M.E. Porte$\mathrm{ra}^{8)}$ modelu tworzenia wartości dodanej przez pionowo zintegrowane przedsiębiorstwo, na rzecz coraz szerszej współpracy z firmami i instytucjami zewnętrznymi poprzez rozwijanie z nimi powiązań kooperacyjnych - tzw. eksternalizacji. Trend ten skutecznie wykorzystała firma, Dell, która w 2004 roku stała się światowym liderem pod względem liczby sprzedanych komputerów.

\section{Powstanie nowych modeli biznesowych}

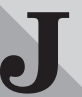

eśli model działalności biznesowej zdefiniuje się jako to, czym firma się zajmuje oraz w jaki sposób konfiguruje posiadane przez siebie zasoby i kompetencje ${ }^{9)}$, to należy stwierdzić, że możliwość „rozczłonkowywania” łańcucha tworzenia wartości sprawia, że KTN mogą wprowadzać i realizować nowe modele biznesowe.

Pod koniec lat 90. ub. wieku zmianom zaczęły ulegać dotychczasowe modele prowadzenia działalności gospodarczej ${ }^{10)}$. Było to związane z postępem w dziedzinie komunikacji, który umożliwił wzrost częstotliwości kontaktów biznesowych i ich jakości, oraz stop- niowym obniżaniem kosztu związanego z interakcja i coraz bardziej pogłębiającą się specjalizacją. Cechy, które wcześniej decydowały o sukcesie firm, a więc ich wielkość i rozbudowana struktura wewnettrzna, zaczęły spowalniać ich działalność i krępować możliwość elastycznego reagowania na zmiany rynkowe. Dlatego też, w odpowiedzi na zmiany w otoczeniu biznesowym, firma IBM zmuszona była do zmiany profilu swojej działalności z produkcji komputerów i oprogramowania na dostarczanie zintegrowanych rozwiązań systemowych. Obecnie, w ten właśnie sposób IBM wykorzystuje wcześniej zdobytą wiedzę i doświadczenie.

Alternatywą dla stosowanej wcześniej internalizacji okazała się sieć niezależnych firm, która swoją strukturą organizacyjną przypomina organizm zbudowany z komórek. Działania, które wcześniej uważane były przez korporacje za kluczowe (jak na przykład produkcja lub opracowywanie gotowych komponentów), zaczęły być zlecane wyspecjalizowanym zewnętrznym poddostawcom, którzy byli w stanie wykonać je szybciej i efektywniej. Nowy, coraz częściej praktykowany przez KTN, model biznesowy wspiera organizację, której przewaga konkurencyjna oparta jest na specjalizacji i sieciowości powiązań. Zaobserwować można, że znaczne zwiększenie liczby wyspecjalizowanych firm zmienia strukture nie tylko sektora komputerowego, lecz innych, w tym także farmaceutycznego i samochodowego. W efekcie powszechnego stosowania outsourcingu oraz powiązań partnerskich o różnym stopniu zależności, zaobserwować można wyłanianie się tzw. organizacji bez granic ${ }^{11}$ (boundaryless organization). Jej cechą charakterystyczna jest umiejętność docierania „na bieżaco” do niezbędnej wiedzy, zasobów, a nawet gotowych innowacji poprzez tworzenie wielu nowych powiązań biznesowych. Nowe formy współpracy doprowadzić moga do tzw. wirtualnej integracji. Zjawisko to oznacza powstawanie sieci niezależnych firm, które ściśle współpracują ze sobą w zakresie rozwijania i komercjalizacji określonej technologii.

Zmiany te w bardzo trafny sposób obrazuje przykład firmy Dell, której dominująca pozycja rynkowa osiągnięta została poprzez specjalizację w procesie składania komputerów i znaczne rozszerzenie skali współpracy z firmami zewnętrznymi w pozostałych obszarach biznesowych.

Firmy stojacce na czele takich sieciowych organizacji potencjalnie będą w stanie osiągać sukces rynkowy poprzez efektywne wykorzystywanie zasobów i umiejętności swoich partnerów ${ }^{12)}$.

\begin{tabular}{|l|c|}
\hline & \multicolumn{1}{|c|}{$1960-1980$} \\
\hline Maszyny & Canon, Nikon, Applied Materials \\
\hline Surowce & \\
\hline Komponenty & \\
\hline Projektowanie & \\
\hline Montaż & \\
\hline System operacyjny & \\
\hline Oprogramowanie & \\
\hline Dystrybucja & \\
\hline Serwis & \\
\hline
\end{tabular}

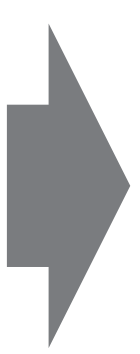

\begin{tabular}{|l|c|}
\hline \multicolumn{1}{|c|}{ 1990-2005 } \\
\hline Maszyny & Canon, Nikon, Applied Materials i inni \\
\hline Surowce & Monsanto, Sumitamo Metal i inni \\
\hline Komponenty & Intel, Micron, Quantum, Komag... \\
\hline Projektowanie & IBM, Compaq, Dell, Gateway, HP... \\
\hline Montaż & Selectron, Celestica... \\
\hline System operacyjny & Microsoft \\
\hline Oprogramowanie & Microsoft, WordPerfect, Lotus, Borland... \\
\hline Dystrybucja & DELL \\
\hline Serwis & Samodzielne firmy \\
\hline
\end{tabular}

Rys. 1. Proces „rozczłonkowywania” lańcucha tworzenia wartości w sektorze komputerowym na przestrzeni ostatnich 50 lat

Opracowanie własne na podstawie: C.M. CHRISTENSEN, M.E. RAYNOR, M. VERLINDEN, Skate to Where the Money Will Be, „Harvard Business Review”, listopad 2001, Reprint 0110D, s. 76; V. KAPUR, J. PETERS, Ready or Not, Here it Comes High-Tech 2005, IBM Institute for Business Value, 2002, s. 5-10, www-1.ibm.com/services/us/imc/pdf/g510-9162-00-readyor-not-here-it-comes-high-tech-2005.pdf. 


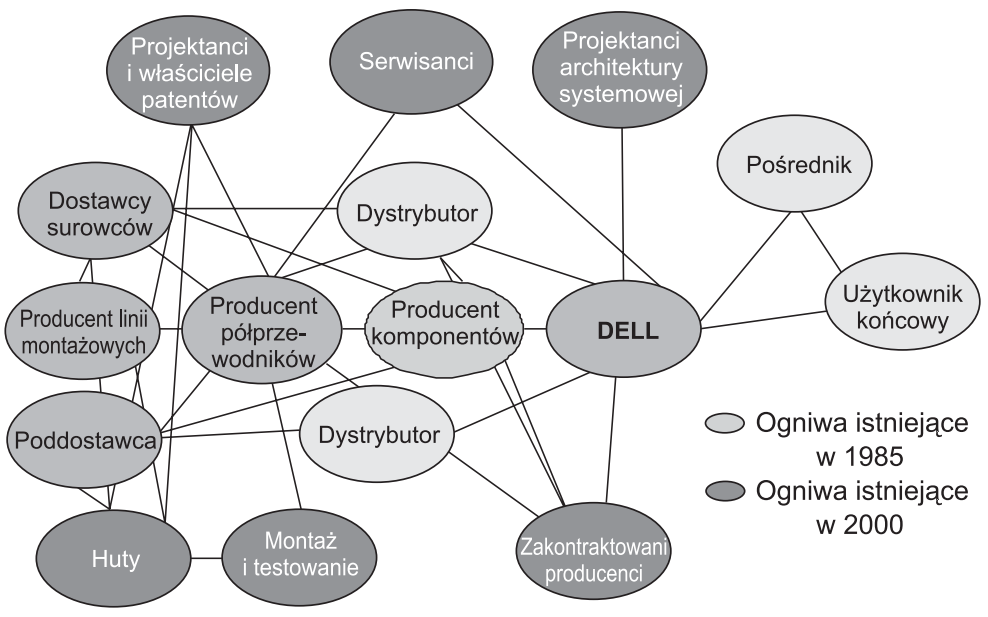

Rys. 2. Nowa, sieciowa struktura zależności w sektorze zaawansowanych technologii na przykładzie Dell

Źródło: C. BEGUE, P. BRODY, Supply Chain Collaboration in the Electronics Value Chain, IBM Business Consulting Services 2002, s. 2; K.L. KRAEMER, J. DEDRICK, Dell Computer: Organization of a Global Production Network, op.cit., s. 3.

\section{Implikacje dla rozwoju KTN}

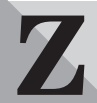

miany modeli biznesowych, spowodowane przez rearanżację łańcucha tworzenia wartości oraz struktur organizacji sprawiły, że niektóre KTN, szczególnie te z sektora zaawansowanych technologii, coraz częściej zaczęły organizować swą działalność wokół jednej z dwóch formy działań rozwojowych. Chodzi o koncentrowanie się na wybranej umiejętności, albo o łączenie wybranych umiejętności pochodzących z zewnątrz w ramach łańcucha tworzenia wartości ${ }^{13)}$. Obie możliwości dotycza działań odbywających się w sieciach współpracujących firm i wymagaja „,wychodzenia” KTN poza granice własnej organizacji.

Pierwsza z nich odnosi się do sytuacji, w której tworzony model biznesowy oparty jest na wybranej części organizacji, której działalność opiera się na wyjątkowej i trudnej do imitacji umiejętności. Za przykład posłużyć może firma IBM, której strategia rozwoju coraz częściej wiązana jest z licencjonowaniem własności intelektualnej ${ }^{14}$. Druga z wymienionych form działania odznacza się dążeniem do stworzenia takiego zestawu umiejętności, który w ramach całego łańcucha tworzenia wartości, a więc zarówno KTN, jak też jej partnerów zewnętrznych, pomoże osiagnąć przewagę konkurencyjną. Za przykład posłużyć może firma Dell, która posiada wyjątkowe umiejętności w zakresie montażu i dystrybucji komputerów. Firma ta dążyć będzie do zachowania swojej konkurencyjności w obszarze montażu i dystrybucji, przy jednoczesnym wspieraniu tej działalności przyswajaniem i wdrażaniem nowych rozwiązań technologicznych, potrzebnych w nowych generacjach komputerów, opracowanych poza własną organizacją.

\section{Wnioski dla polskich przedsiębiorstw}

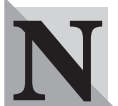
owe modele biznesowe wymagaja od KTN także zmiany w podejściu do zarządzania. Pogłębiająca się sieciowość działania sprawia, że z jednej strony zmniejszeniu ulega kontrola menedżerska sprawowana przez KTN nad tworzona gama komponentów, z drugiej zaś zwiększa się presja na tworzenie wartości dodanej przez cała sieć zorganizowana wokół KTN. Dla polskich przedsiębiorstw oznacza to możliwość umiędzynaradawiania działalności poprzez kooperację z KTN, bez konieczności ponoszenia wysokich kosztów związanych z bezpośrednimi inwestycjami gospodarczymi za granica. Rosnace możliwości kooperacyjne wymagaja jednak od polskich partnerów zdolności do współpracy w sieci firm tworzących wartość dodaną oraz stawiają nowe, większe wymagania związane z jakością i przydatnością opracowywanych w Polsce innowacji. Ważnym aspektem stanowiącym warunek uczestniczenia w takiej wymianie jest umiejętność rozpoznania potrzeb potencjalnych partnerów i odpowiedniego zaspokajania ich tak, aby stać się zaufanym i cenionym partnerem w sieci. Dzięki dopasowaniu swojej oferty do wymagań KTN, a także poprzez wykorzystanie tworzonej przez KTN latami globalnej organizacji, polskie firmy maja potencjalną możliwość wejścia w niszę rynku globalnego.

Michat Marte doktorant w Instytucie Studiów Międzynarodowych Kolegium Ekonomiczno-Społeczne Szkoła Główna Handlowa w Warszawie

\section{PRZYPISY}

1) World Investment Report 2004: The Shift Towards Services, New York and Geneva 2004, s. 70-78.

2) J. CANTWELL, L. PISCITELLO, Accumulating Technological Competence - Its Changing Impact on Corporate Diversification and Internationalisation, „Industrial and Corporate Change", vol. 9, 2000, s. 21-51.

3) Ö. SÖLVELL, J. BIRKINSHAW, Multinational Enterprises and the Knowledge Economy: Leveraging Global Practices, [w:] J.H. DUNNING, Regions, Globalization, and the Knowledge-Based Economy, Oxford University Press, Oxford 2000, s. 90.

4) L. BRYAN, J.N. FRASER, Getting to Global, ,The McKinsey Quarterly" 1999, s. 76.

5) J.A. CANTWELL, L. PISCITELLO, Accumulating Technological..., op.cit., s. 25-44.

6) A. SCHIBANYI, T.J. HÄMÄLÄINEN, G. SCHIENSTOCK, Interfirm Co-operation and Networking: Concepts, Evidence and Policy, OECD 2001, s. 3-5, http:// www.oecd.org/searchResult/0,2665,en_2649_201185_1_ $1 \_1 \_1,00$. html

7) J.C. AURIK, G.J. JONK, R.E. WILLEN, Rebuilding the Corporate Genome. Unlocking the Real Value of Your Business, John Willey \& Sons, Hoboken 2003, s. 51-78.

8) M.E. PORTER, Competitve Advantage: Creating and Sustaining Superior Performance, Free Press, New York 1985, s. $11-15$.

9) Definicja za prof. T. MALONE z MIT Sloan School of Management, [w:] Michaels M. ZUCKERMANN, Speed: Linking Innovation, Process and Time to Market, The Conference Board, maj 2000, s. 13 oraz K. OBŁÓJ, Tworzywo skutecznych strategii, PWE, Warszawa 2002, s. 97.

10) J. HAGEL, M. SINGER, Unbundling The Corporation, ,The McKinsey Quarterly” 2000, nr 3, s. 148-161.

${ }^{11)}$ C. SNOW, R. MILES, B. ALLRED, Managing LeadingEdge Multinational Corporations, [w:] B. McKERN (red.), Managing the Global Network Corporation, Routledge, London 2003, s. 212-214.

12) J. HAGEL, Spider Versus Spider, „The McKinsey Quarterly", nr 1, 1996, s. 4-18, J. HAGEL, On Strategy, "McKinsey Quarterly Anthology” 2000, s. 71-80.

13) J.C. AURIK, G.J. JONK, R.E. WILLEN, Rebuilding the Corporate Genome..., op.cit., s. 55-60.

14) UNCTAD, World Investment Report 2005, Transnational Corporations and the Internationalization of $R \& D$, New York and Geneva, s. 169. 